\section{Poor farmers' community empowerment model trough nonformal education of catering waste utilization for catfish food in industrial area}

Sutisna, Anan

Jakarta State University, Indonesia (ananplsunj@yahoo.com)

Received: 12 November 2014 Available Online: 10 January 2015

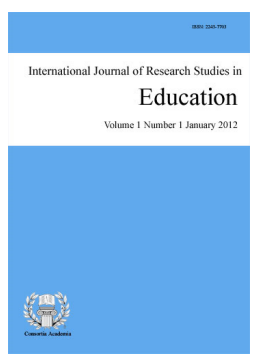

ISSN: 2243-7703 Online ISSN: 2243-7711

OPEN ACCESS

\title{
Abstract
}

The research aimed at describing poor farmers' community empowerment model trough non formal education of catering waste utilization for catfish food in industrial area. Method used was mixed method with qualitative and quantitative approach. Data collection was done by questioner and Focus Group Discussion. Data was analyzed with qualitative descriptive. Result showed that poor farmers are people without income. Poor criteria are classified into physical and non-physical. Physical criteria comprised of landownership, house ownership and asset owned. Whilst, non physical criteria consist of occupation, income, and expense. There were three community empowerment strategies such as: 1 . focused on basic training to independent business or work, 2. focused on entrepreneurship skill, and 3. strategy that focused on business facilitation or seeking for developmental alternatives.

Keywords: poor farmers' community; empowerment; non-formal education 


\section{Poor farmers' community empowerment model trough nonformal education of catering waste utilization for catfish food in industrial area}

\section{Introduction}

The number of poor people nationwide for the last three years has decreased, in the year 2011 was $12.36 \%$, 2012 for $11.66 \%$ and in 2013 amounted to $11.37 \%$ or 0.53 million of 28.07 million people (BPS, 2013). While in the West Java province alone, number of poor people in 2013 reached 350,000 and increased to 450,000 people in 2014. Of the 450,000 number of poor people, 151.6 thousand people were in Bekasi (BPS, 2014). Ironic condition where Bekasi is the most dominant industrial region in improving the economy. The presence of 18 industrial zones with 5 biggest industrial zones such as MM2100, JABABEKA, EJIP, LIPPO, Bekasi Fajar Industrial Estate and Hyundai. Overall industrial estates in Bekasi has a total area of 6462.4 hectares, with a total number of 864 units of industrial enterprises, and provide employment for 449608 people (BPS, 2012). However, the poor in Bekasi still reach over 151,000 people, so the attention of all parties is needed to resolve the problem.

These data above draw an environment condition where there is a set of resources, both natural resources and human resources that could have an effect in human life. In particular, we often use the term environment to mention everything that affects the survival of all living creatures on earth. Where the environment is the unity of space with all the objects and unity of living beings including humans and their behavior that accomplishes the life and welfare of humans and other living beings (Aminudin, 2013). Environment and humans in fact is a unity that cannot be separated from each other, both will affect each other. Environmental conditions will be determined by human behavior and vice versa. Therefore, non-formal education has a mission to foster and develop an intelligent human being, while an intelligent man has the ability to respond quickly to the environment, able to analyze the environment, act and behave actively in problem solving, and oriented towards the progress of life in the future (Sudjana, 2004).

Community empowerment programs as efforts made by individuals or institutions which is based on the potency of society environment, whose main objective is to improve the quality of life through the utilization of the resources available to them and insists on the principle of social participation (Suharto, 2009). A community development effort is considered successful if the community group became the driving force, not only as an object. Community as a subject to determine the choice of the right strategy is expected to improve the ability and self-reliance, empowerment can only occur when citizens participation exist. Because of that, empowerment is a process and purpose. Empowerment process is a series of efforts to improve the ability of communities to achieve prosperity and well-being. The purpose of empowerment refers to the state or the results to be achieved by a social change, which empowered the poor, has no power or has the knowledge and ability in meeting their needs whether physical, economic, and social.

Community empowerment can be seen from three sides (1) create an atmosphere or climate that allows potential developing society (enabling), (2) strengthen the potential or community-owned power (empowerment), (3) empowering also means the sense of protecting vulnerable groups that are not oppressed by powerful groups, and prevent unequal competition and exploitation of the strong over the weak (Sumodiningrat, 1996). Based on the above, community empowerment program being an alternative is non-formal education that is an education system based on the needs of the community by providing appropriate training potential of the surrounding natural environment. As the opinion Kindervatter (1979), empowering will be defined as: People Gaining an understanding of and control over the social, economic, or political forces and in order to improve Reviews their standing in society.

Society is a human resource that has potency as a pioneer of empowerment. Law Number 20 Year 2003 on 
National Education System Article 54 Paragraph 2 states that the public can participate as the source, implementers, and users of educational outcomes (Sudjana, 2004). In non-formal education has a principle of community, by the community and for the community. While natural resources have the potential to be used and managed wisely in a particular area. Such as the existence of unused land excavated brick factory in the industrial area targeted by some members of the community in the East Cikarang Bekasi to be used as a catfish culture. Cikarang East region is an area suitable for the cultivation of catfish. There have been some farmers who have been empowered to take advantage of the environment.

Potential catfish farming has the support of the Department of Fisheries Bekasi by providing counseling, supervision and access to marketing. The provision of seeds or funding is made easier because it has been the potential in the business community to develop the economy in Cikarang East Bekasi. This catfish culture takes 6 months to produce Catfish that can be sold into the market and Supermarket. Catfish prices today could reach $10,000 / \mathrm{kg}$. Currently catfish become one of the leading commodities in the field of fisheries. Freshwater fish that has a grayish-white color has a distinctive flavor and quite high in protein. In addition, the cholesterol levels in the catfish are very low, so the fish is much chooses to consume by community as it is safe for health. Catfish is omnivor fish (eating everything) and tends to be a carnivore (eating animals/meat). In nature, catfish eat small fish, worms, insects, and seeds, pieces of leaves of plants, grasses, and small shrimps. In maintenance can eat catfish feed pellet (Ghufran \& Kordi, 2010). Artificial feed pellet is relatively expensive, so farmers use waste derived from food catering employees in the company as well as the rest of the market. Use of catering waste is one method to minimize expenditures for the purchase of feed, thus gaining greater profits.

Cikarang East Bekasi region is a potential area for cultivation of catfish. In addition to the many former excavation brick factory also supported by the existing water source. Feed can be supplied from the many catering waste generated by companies in the industrial area. Opportunities for catfish farming can be done in two areas of activity, namely: (1) seeding activities and (2) as a food fish rearing activities. Seeding activity is an attempt to produce seed in size 2-3 inch/tail. Catfish culture as the fulfillment of this seed has a pretty good prospect because of the demand for seedlings is also quite high. Catfish culture as seed stocks requires a relatively short time so that the turnover is faster. Catfish culture in the category of enlargement is usually done when the seedlings catfish weighs for 8-12 grams each, and after 6 months can reach 600-700 g each. Most catfish farmers harvest after 3 to 4 months of age because the catfish market demand with lower weight per fish. Catfish culture as seed and fish consumption have a business opportunity that is equally beneficial. Catfish farming activities carried out in the region of East Cikarang Bekasi mostly in the category of enlargement. The farmers receive seed supply then was raised for 3-4 months, then harvested and ready to be marketed. Market demand mostly come from auction sites or restaurant that serves catfish -based foods.

In terms of production, some things are the hallmarks of catfish. First, this fish is one of the voracious fish food. Not surprisingly, at the age of six months, catfish can reach between 35-40 cm long. Secondly, the maintenance does not require running water. In general, there are several cultivation activities in the field of fisheries, includes hatchery, nursery, and enlargement. All of these activities are interconnected. With the pattern of production that relies on such activities, each person can choose the activities that will be engaged in accordance with the ability of capital, local conditions, market opportunities, and facilities availability (Khairuman \& Sudenda, 2002).

Based on the background of the problems described above we can identify some problems as follows:

Dow environmentally damaged industrial estates can be reused for productive activities by poor farmers?

$>\quad$ How catering waste can be used as feed for catfish by farmers?

$>$ What is the profile of poor farmers with a model of community empowerment through non-formal education in order to improve people's lives? 


\section{Methods}

This study used a mixed method, namely the qualitative and quantitative approaches. Where quantitative approach was aimed at obtaining data about the ownership of land, houses and assets as well as income and expenses. While qualitative was used to obtain information about the environment and the use of catering waste. This study was descriptive because it gave an idea as carefully as possible about an individual, a state, or sign or particular group. Assessment was a type of descriptive research (Sugiyono, 2008). In this case, the research tried to describe the strategy of empowerment of poor farmers through non-formal education by utilizing catering waste as catfish food in the industrial area. This study was carried out on poor farmers in the village of catfish farming Cipayung District of East Cikarang - Bekasi West Java Province. Research time was 5 months starting in January until July 2014. With 120 cultivating catfish farmers as total population. Sampling was purposive; with the criteria of cultivating catfish farmers that were poor with the characteristics of (1) do not have a steady job, (2) Rent swamp as cultivating place (3) cultivating farmer was tenants, as many as 30 people were poor farmers as respondents.

In accordance with research on poor farmer community empowerment model trough non formal education of catering waste utilization for catfish food in industrial area it is necessary to operationally defined as follows: Community empowerment is a process, manner, and act making power, such as the ability to do something or the ability to act in the form of sense, initiative or effort. So the strategy of community empowerment is a concept or a system of instructional or learning to develop patterns of behavior of farmers in aspects of knowledge, skills or attitudes to achieve the goal. Non-formal education is any activity undertaken by members of the community in improving the knowledge, attitudes and skills appropriate to the urgent needs through training and skills courses. Data were collected through questionnaires and focus group Disscation. Data were analyzed using descriptive statistics by percentage calculation that will be used to describe or explain phenomena that occur. Therefore, after the data were collected and analyzed to determine poor farmer community empowerment model trough non formal education of catering waste utilization for catfish food in industrial area in the region, using the following formula:

$$
\mathrm{P}=\frac{\sum \mathrm{Xi}}{\mathrm{N}}
$$

Where : P: Percentage of data; $\sum \mathrm{Xi}$ : The number of incoming data; $\mathrm{N}$ : Number of respondents who studied

\section{Results}

The results of this study were obtained from 30 poor farmers in the village of catfish farming Cipayung District of East Cikarang - Bekasi West Java Province. Identity of the respondents sere describe as follows: (1) age of the respondents between 36-57 years 73\%, (2) gender are all male 100\%, (3) all farmers work 100\%, and (4) latest education was elementary-school as much as $70 \%$. Based on the research objectives, the research results show the following:

$>$ The use of environmentally damaged industrial estates that can be reused for productive activities by poor farmers can be described as follows: (1) knowledge to empower the potency of environment was $100 \%$, (2) knowledge of the catfish farming steps was $100 \%$, (3) knowledge on the use of brick quarry land for catfish farming was $100 \%$, (4) an understanding about changing environment from unused into something useful was $100 \%$, (5) the application about the use of environmental resources as a means for businesses earning was $100 \%$, (6) the analysis ability to find innovation in using natural about $93 \%$, (7) the attitude of the people aware of the potential for utilizing the nature around them was $97 \%$, (8) skills in utilizing available environmental resources was $90 \%$ (9) skill in changing bricks quarry land to for catfish farming land was $100 \%$. 
$>$ Utilization of catering waste used as by farmers as catfish food can be described as follows: (1) knowledge of the use of catering waste as catfish food was $100 \%$, (2) knowledge of the catering waste treatment was $100 \%$, (3) the ability to considered that the use of economics side of catering waste as catfish food was $100 \%$ and (4) catering waste processing skills into catfish food was $100 \%$.

$>$ Profile of poor farmers that are empowered through non-formal education in order to improve people's lives can be described as follows: (1) an understanding of the activities that improve the local economy was $97 \%$, (2) understanding in increasing community participation was 97\%, (3) understanding about improving the of income was $100 \%$, (4) understanding in increasing creativity was $100 \%$, (5) Skill in predicting the profits from the sale of catfish was $100 \%$, (6) attitude in creating opportunities for people was $100 \%$, (7) attitude in creating new livelihood to the community was $100 \%$, (8) Manner in creating the job market and business independence was $100 \%$, (7) the attitude to solve the economic problem of society was $100 \%$, (8) the average income of farmer for Rp. 600.000 , - / month was $100 \%$, (9) the average expenditure of farmers at above Rp. 900.000, - / month was $100 \%$ and (10) the ownership of the house / land own was $75 \%$ and $25 \%$ rent.

Empowerment Strategies of poor farmers through non-formal education is done by three models of strategy firstly for poor farmers who do not have the knowledge and attitudes in performing catfish culture program were focused to enroll in basic training to independent business or able to work. Secondly farmers who have been able to do catfish culture were focused on entrepreneurial skills training start from feasibility study to manage a successful business, and a third strategy for farmers and land owners who have limited capital program was focused on facilitating the business and alternative business development by using banking services for small and medium entrepreneurs.

\section{Discussion}

Based on the analysis of the strategy of poor farmers community empowerment model trough non formal education of catering waste utilization for catfish food in industrial area for the welfare of the people in the village Cipayung District of East Cikarang - Bekasi. This catfish farming activities initiated from one former employee of Fish Seed (BBI). In the past when he was working at BBI had attended a training on catfish farming an along with a villager for Cipayung. Returning from training the person found the catfish in aquarium are starving and the aquarium next to it with uduk rice, and then he took the initiative to feed the catfish with uduk rice. The person who happened to have a chicken coop and a catfish pond underneath there, then the rest of the catering company in the Cikarang industrial area accidentally discharged into Cipayung village which was originally only used to feed chickens, is also used to feed catfish.

But as time went on previous catfish farming requires more capital and the level of care that complicated replaced with other catfish farming. Cipayung Villagers who had joined the training was seen sleeping area in excavated brick industry was left alone by their owners, and rented for farming catfish. Residents in the local area prospects catfish aquaculture conducted an earlier resident, interested to open a catfish farming. The catfish farmers who originally only had brick production business, currently has other business as catfish aquaculture farmers. Former brick quarry land was not only used alone, even rented at a price according to the agreement. Catfish aquaculture feed is not difficult in to get, because they get it by utilizing residual waste from the food catering employees of companies in the industrial area in Cikarang. Catering waste previously disposed of with frees of charge by the janitor and for anyone who wants to process them rewarded by a janitor. But the prospects for the current catfish aquaculture waste at stake once per car tub priced between Rp. 250,000. Not only utilize the facilities and infrastructure of the local area, including labor for the cultivation of catfish using labor from around the site with the aim of reducing unemployment.

Disadvantages of catfish farming activities in the Cipayung village was the absence of a coordinating group farming activities, so only limited on private cultivation catfish managed by the individual. Catfish farming 
activities in the Village area of Cipayung majorly engaged in rearing of seed measuring 2 inches and enlargement fish (fish 3-5 months old) weighing less than $1 \mathrm{~kg}$. Seed price with a size of 2 inches was Rp. 220 each, while the price of a kilogram was Rp.10.300. Prediction of the advantages and disadvantages of catfish farming, if harvesting above $25 \%$ of the planted seedlings can be said good, but the opposite if the harvest was below $25 \%$ it is definitely a loss. The factors causing the loss are the died seedlings or discharged due to irregular weather conditions, natural disasters such as floods, and pests and diseases.

Analysis of catfish farming business according to production costs incurred respondents with a land area of $7 \mathrm{~m}$ long $\mathrm{x} 4 \mathrm{~m}$ wide $\mathrm{x} 7 \mathrm{~m}$ water depth capacity of 15,000 . Production costs include rent of land needed $\mathrm{Rp}$ 3,000,000 - Rp.10.000.000, - per year depending on the area of land and an agreement between the tenant and the owner of the land (for land ownership itself does not need to pay the rent of land), then the purchase of fish seed was Rp. 220, - / tail x 15,000 = Rp.3.300.000, -, purchase of feed in the form of pellets was Rp. 900,000, -, catering waste for 500.000, - / month, a drug for fish for Rp.60.000, - / month, labor costs for Rp.1500 / kg multiplied by the crop. Then, if the income catfish planted seeds can be harvested all, estimates of general accounts for 6 months of harvest $1 \mathrm{~kg}$ contains 3 tails so 15000: $3=5000 \mathrm{~kg}$ multiplied by the selling price Rp.10.300, - / kg = Rp.51.500.000, -. As for labor expenses 5,000 kg x IDR 1,500 = Rp. USD 7,500,000 plus the purchase of seed. 3,300,000, Rp fish medicine. 360.000, - Rp feed pellets. Rp 900,000 and catering waste. 3.000.000, -. Total spending of Rp. 15.06 million, - So profit reached Rp. 36.44 million (Rp. 51.5 million - Rp. 15.06 million).

\section{Conclusion}

Based on the research results, it can be conclude that: Utilization of industrial estates environment (brick factory) that has been damaged so that it can be used again for catfish aquaculture by poor farmers based on knowledge, attitudes and skills possessed. Utilization of catering waste used as catfish feed by cultivating farmers hopefully will minimize the cost of production, so the catfish farming can be more profitable. Profile of poor farmers empowered through non-formal education in order to improve the living standard were trained for catfish farming and catering waste utilization of catfish food. Empowerment strategies of poor farmers through non-formal education was done with three models of strategy: (1) for poor farmers who do not have the knowledge and attitudes in performing catfish culture basic training is focused to independent business capability. (2) for farmers who have been able to do a catfish culture is focused on entrepreneurial skills training start from performing a feasibility study to manage successful businesses, and (3) for farmers as owners of the land and have limited capital, is focused on business facilitation and alternative development by using banking services.

\section{References}

Aminudin. (2013). Keeping the environment with local wisdom. London: Titian Science Central Bureau of Statistics [BPS]. (2012). Data on poverty figures Bekasi. Bekasi. Central Bureau of Statistics [BPS]. (2013). The data of the national poverty figures. Jakarta. Central Bureau of Statistics [BPS]. (2014). Data on the number of poor people of West Java Province. Bandung Ghufran, M., \& H Kordi K. (2010). Catfish aquaculture in swimming sheeting. London: Lily Publisher.

Khairuman, \& Sudenda, D. (2002). In intensive cultivation patin. Depok: AgroMedia Library.

Kindervatter, S. (1979). Non-formal education as an empowering process with case studies from Indonesia and Thailand. USA: Center for International Education University of Massachusetts.

Sudjana. (2004). Non-formal education: Insights, historical development, supporting philosophy and theory, and principles. Bandung: Falah Productions

Sugiyono. (2008). Educational research methods quantitative approaches, Qualitative, and R\&D. New York: Alfabeta.

Suharto, E. (2009). Building communities empowering people. Bandung: PT Refika Aditama. Sumodiningrat, G. (1996). Empowering communities. Jakarta: Penakencana Nusadwipa. 